\title{
Increasing energy and protein use efficiency improves opportunities to decrease land use, water use, and greenhouse gas emissions from dairy production
}

\author{
Robin R. White ${ }^{\mathrm{a}, *}$ \\ a Department of Dairy Science, Virginia Tech, Blacksburg, VA 24061, United States
}

\section{A R T I C L E I N F O}

\section{Article history:}

Received 12 November 2015

Received in revised form 27 March 2016

Accepted 29 March 2016

Available online $\mathrm{xxxx}$

\section{Keywords:}

Nutrition

Feed efficiency

Dairy

Land use

Water use

Greenhouse gases

\begin{abstract}
A B S T R A C T
The objectives of this study were to construct a farm-scale diet optimization model to identify opportunities to reduce land use, water use, and greenhouse gas (GHG) emissions within dairy production systems and to assess how improved energy and protein use efficiency affect opportunities to reduce these environmental impacts (EI) of dairy production systems. Non-linear programming was used to adjust monthly diets fed to 10 cattle groups to minimize EI associated with an average United States dairy farm. System boundaries extended from the inputs to the cropping system to the dairy farm gate. The effects of improved feed efficiency were modeled as a $15 \%$ decrease in maintenance energy or metabolizable protein requirements. Least-cost optimization was used as a baseline. A total of 28 scenarios were simulated which varied in objective, biological efficiency, and allowable cost increase. Objectives included minimizing land, water, or GHG emissions individually or all together. Biological efficiencies reflected either currently achieved efficiencies, improved energy efficiency, improved protein efficiency or improved energy and protein efficiency. Allowable cost increases were adjusted from $1 \%$ to $20 \%$ above baseline. Baseline land use $\left(1.20 \mathrm{~m}^{2} / \mathrm{kg}\right.$ milk), water use $\left(1.10 \mathrm{~m}^{3} / \mathrm{kg}\right)$ and $\mathrm{GHG}$ emissions $(0.70 \mathrm{~kg} \mathrm{CO} 2 \mathrm{e} / \mathrm{kg})$ agreed with established values for U.S. dairies. Within the allowable cost range, EI metrics could be simultaneously reduced by 4.4 to $25.5 \%$. When both energy and protein efficiency were improved, land use, water use, and GHG emission reductions ranged from 23.4 to 35.5\%. Diminishing environmental returns to cost increases were apparent. Cost of achieving a $25 \%$ reduction in the environmental impacts considered in this study was decreased $78.9 \%$ when energy and protein efficiency improved compared with the national average production efficiency scenario. Improving energy- and protein-use efficiency of dairy cattle represents a promising way to reduce land use, water use, and GHG emissions without sacrificing profitability.
\end{abstract}

(c) 2016 Elsevier Ltd. All rights reserved.

\section{Introduction}

Global population is expected to reach 9.4 billion by 2050 (U.S. Census Bureau, 2013) and demand for meat and milk is expected to rise substantially (Delgado, 2003). These global dynamics suggest a need to improve the sustainability of food production systems. Optimizing animal nutrition is one method of improving sustainability of ruminant production systems (White et al., 2014, 2015). Within U.S. dairy production, emphasis has been placed on single-target management goals such as minimizing $\mathrm{N}$ excretion (Kebreab et al., 2001), controlling ammonia emissions (Hristov et al., 2011) or reducing phosphorus elimination (Ghebremichael et al., 2007; Spears et al., 2003). Within the farm system, these single-target goals often require trade-offs and net increases in other important environmental metrics (Tozer and Stokes, 2001; White et al., 2014).

\footnotetext{
* Department of Dairy Science (0315), Litton Reaves Hall Room 2470, Virginia Tech, 175 West Campus Drive, Blacksburg, VA 24061, United States

E-mail address: rrwhite@vt.edu.
}

Whole-farm models have been constructed to better understand the whole-system environmental impact of dairy farm management (Beukes et al., 2008; Capper et al., 2009; Crosson et al., 2011; del Prado et al., 2009; Rotz et al., 2010; Shalloo et al., 2004) and have revealed a strong relationship between efficiency and reduced environmental impact (Capper and Bauman, 2013). Improving feed efficiency is one method of improving productivity. Animal nutrition research has focused on improving energy- and protein-use efficiency; however, the potential environmental benefit of these research avenues has not been well investigated.

The objective of this study was to construct a whole-farm diet optimization model to identify opportunities to reduce land use, water use and greenhouse gas ( $\mathrm{GHG}$ ) emissions within dairy production systems. A subsequent objective was to assess how improved energyand protein-use efficiency could affect the opportunities to reduce environmental impact of dairy production systems. It was hypothesized that improved energy and protein efficiency would provide substantial opportunity to reduce land, water, and GHG emissions attributable to milk production. 


\section{Materials and methods}

A multi-objective optimization model (Tozer and Stokes, 2001; White et al., 2014, 2015) was developed to quantify diet cost, land use, water use, and GHG associated with dairy production systems in the U.S (Fig. 1). The model simulated a 1-year timeframe. Inputs to the model included cattle populations, weights, nutrient requirements, dry matter intake, and feed composition. The model used non-linear programming to adjust diets fed to 10 cattle groups to minimize diet cost or land use, water use, and GHG emissions per kg milk produced. The model was run using the Generic Algebraic Modeling System (GAMS; Generic Algebraic Modeling System Development Corporation, 2012). Outputs were compared to previously published estimates of U.S. dairy environmental impact. The environmental and economic benefits of improving nutrient-use efficiency were assessed by optimizing scenarios with improved energy-, protein- or energy- and protein-use efficiency.

\subsection{Model inputs}

\subsubsection{Cattle group specifications and nutrient requirements}

Animal populations were based on culling rates, conception rates, proportion of female calves and the number of mature breeding cows in the herd. In a recent survey of U.S. dairies, $82.2 \%$ of cows were managed on conventional operations (as defined by USDA/APHIS, 2007) and 90.1\% were Holstein (USDA/APHIS, 2007) thus a conventional, Holstein system was modeled. Herd rolling average milk yield per cow was assumed to conform to the national average of $10,219 \mathrm{~kg} / 305 \mathrm{~d}$ (USDA/APHIS, 2007). The equations in this model rely on set notation. Set notation applies a common equation type to a series of elements (cattle populations, feeds, etc.) where some aspect of that equation is unique to each element. All sets are comprised of a series of elements and subsets create secondary groupings of elements in a set (lactating cows within cattle populations, forages within feeds). The sets used herein, their elements, and any subsets are listed in Table 1. Equations and key input parameters governing animal populations are included in Table 2. Cows that failed to conceive were assumed to be culled annually. Culling rate was assumed to increase with age, and cows were culled entirely from the herd at $60 \mathrm{~m}$ of age.
The resultant average culling age was $38 \mathrm{~m}$ of age which is representative of the average U.S. culling rate (USDA/APHIS, 2007).

Net energy and metabolizable protein requirements of the cattle groups were calculated based on National Research Council (2001) nutrient requirements of dairy cattle. Diets were also balanced to ensure sufficient macro ( $\mathrm{Ca}, \mathrm{P}, \mathrm{Mg}, \mathrm{Cl}, \mathrm{K}, \mathrm{Na}$, and $\mathrm{S}$ ) and micro (Co, Cu, I, Fe, $\mathrm{Mn}, \mathrm{Se}, \mathrm{Zn}$ ) mineral and vitamin (A, D, E) supplies. Requirements of minerals and vitamins were calculated following the recommendations of the National Research Council (2001) nutrient requirements of dairy cattle model.

Several nutritional constraints were included in the model (Table 3). Diets were balanced for 10 animal groups $(a)$ on a monthly $(m)$ basis. Each diet needed to contain nutrient $(n)$ concentrations greater than or equal to the required amount $(R e q)$ of each nutrient $(n)$. The amount of a nutrient provided in the diet was the product of dry matter intake (DMI) and the concentration of the nutrient (Conc) in the diet. Total feed consumption needed to be less than the maximum consumption (MaxDM) predicted by National Research Council (2001). Practicality constraints were included to limit the maximum amount of a feed (UpLim) that could be included in the diet. Additionally, minimum dietary acid detergent fiber (ADF) concentrations were constrained to ensure that realistic balances of forages and concentrates were included.

Environmental calculations are detailed in Table 4. Environmental impacts from animals within the model included enteric and manure $\mathrm{CH}_{4}$ emissions along with direct, leached and volatilized $\mathrm{N}_{2} \mathrm{O}$ emissions. An equation presented in Moe and Tyrrell (1979) was used to predict enteric $\mathrm{CH}_{4}$ emissions because this equation was more accurate and precise than other $\mathrm{CH}_{4}$ predictions when evaluated against literature data (Ellis et al., 2010). Tier II methods of the IPCC (2006) were used to calculate manure $\mathrm{CH}_{4}$ and all $\mathrm{N}_{2} \mathrm{O}$ emissions. Manure emission factors (Table 5) were averaged based on the use of manure management systems in the U.S. (USDA/APHIS, 2007). Nitrogen excretion (NE) was calculated based on milk yield and crude protein concentration in the diet with functions specific to stages of production (ASAE, 2005; Thoma et al., 2013b). Greenhouse gas emissions associated with infrastructure (CO2i) were based on electricity use for housing, milk cooling and storage following the values from Capper et al. (2008) and the carbon emissions for generation of electricity in the U.S. (0.18 kg CO2equivalent/kWh; Davis and Diegel, 2010). Drinking water consumption

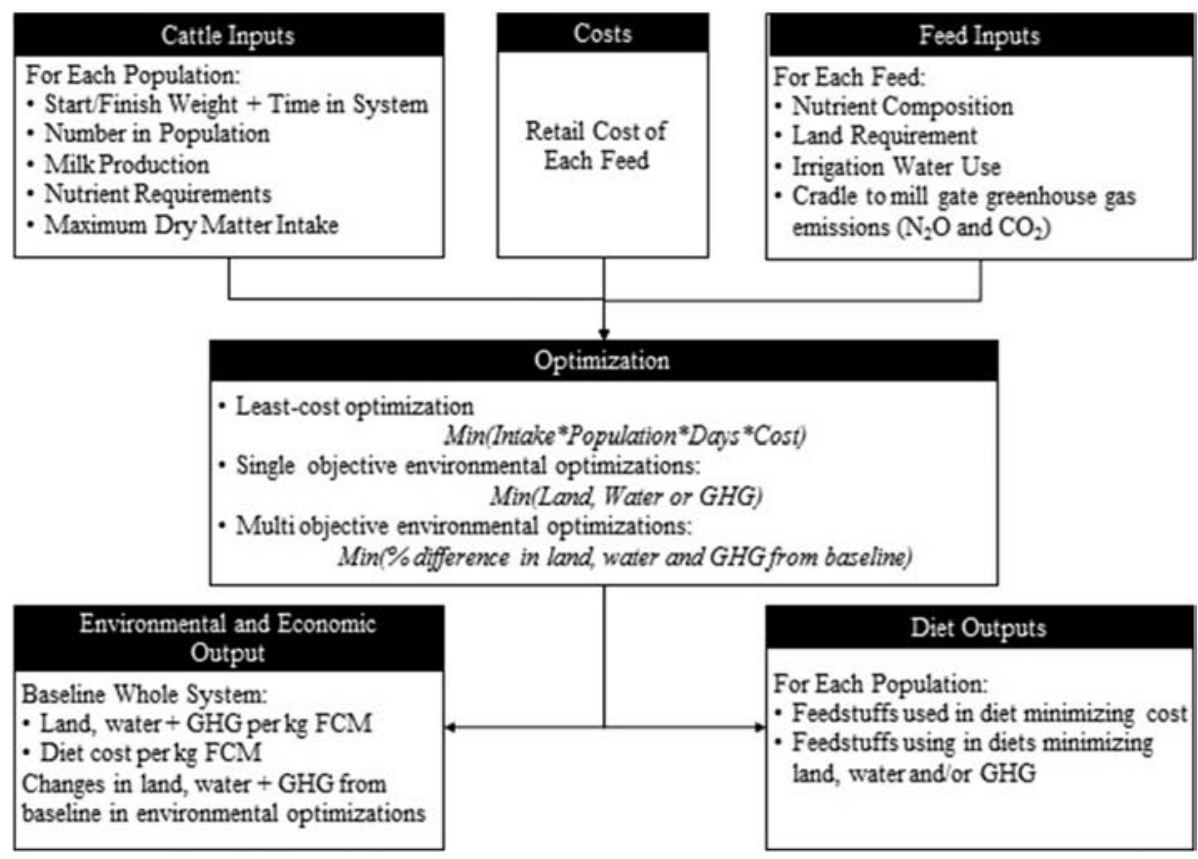

Fig. 1. Representation of dairy farm optimization model. 
Table 1

Definitions and elements of sets and subsets referenced in equations.

\begin{tabular}{|c|c|c|c|}
\hline Set & Set name & Elements or parent set & Element definitions \\
\hline a & Animal groups & $\mathrm{c} 1, \mathrm{c} 2, \mathrm{c} 3, \mathrm{c} 4, \mathrm{c} 5, \mathrm{~b} 1, \mathrm{~b} 2, \mathrm{~b} 3, \mathrm{~b} 4, \mathrm{~b} 5$ & Cows (c) and bulls (b) ranging from 1 year to maturity (by year) ${ }^{\mathrm{a}}$ \\
\hline $\mathrm{f}$ & Feedstuffs & $\mathrm{f} 1, \mathrm{f} 2, \mathrm{f} 3, \ldots, \mathrm{f} 55$ & Feedstuffs available within the model \\
\hline $\mathrm{m}$ & Months & $1 \ldots 12$ & Months (January $=1$ ) \\
\hline 0 & On-farm feeds & $o \subset f^{b}$ & Forages and silages available for on-farm production \\
\hline $\mathrm{p}$ & Animal protein feeds & $\mathrm{p} \subset \mathrm{f}$ & Feather meal, fish meal, blood meal and meat and bone meal \\
\hline $\mathrm{v}$ & Vitamin or mineral feeds & $\mathrm{v} \subset \mathrm{f}$ & Vitamin and mineral feed available within the model \\
\hline 1 & Forages and silages & $\mathrm{l} \subset \mathrm{f}$ & Forages and silages (both on-farm and off-farm \\
\hline $\mathrm{n}$ & Nutrients & ME, MP, ..., VitD & Metabolizable energy (ME), metabolizable protein (MP), macro minerals, micro minerals, vitamins \\
\hline
\end{tabular}

a Elements in the animal population were defined by an alphanumeric code where the letter indicated sex (female, c; male, b) and the number indicates age ( 0 to $1 \mathrm{y}, 1 ; 1$ to 2 $\mathrm{y}, 2$; and so forth).

b The $\subset$ symbol indicates ownership. The subset defined to the left of the symbol is comprised of elements of the set defined on the right side of the symbol.

was calculated as a function of temperature, milk yield, body weight, and sodium concentration in the diet (Meyer et al., 2004). Water use for processing ( $\mathrm{H} 2 \mathrm{OP}$ ) was calculated based on the values from Capper et al. (2008).

\subsubsection{Crop and byproduct production parameters}

Each run of the optimizer adjusted feedstuffs used in cattle diets to achieve an objective. Individual feedstuff nutrient composition, land requirement, water use, and GHG emissions were inputs to the model. These values are listed in the online Supplementary material. Feed composition was sourced from the National Research Council (2001) nutrient requirements of dairy cattle feed library. Many dairies produce a substantial proportion of feed on-farm. Onfarm feeds were restricted to ensure that the amount of on-farm feeds fed did not exceed the amount of feed that could be produced from the available land on farm. Feeds available for on-farm production were forages, hays and silages.

Land use, water use and GHG emissions associated with feed production were sourced from the Agrifootprint database, USDA/NASS (2007); USDA/ERS (2012), and a database maintained by University of
Arkansas (Burek et al., 2014). Crop GHG emissions represented $\mathrm{CO}_{2}$ and $\mathrm{N}_{2} \mathrm{O}$ emissions from the manufacture of inputs to the cropping system through the feed mill gate. Additional GHG emissions accounted for included transport of feeds for off-farm feeds. It was assumed that all grain traveled an average of $1000 \mathrm{~km}$ prior to being fed to cattle. This distance was selected as approximately half of the distance from the Midwest, where most U.S. grain is grown, to the East Coast. Greenhouse gas emissions for freight rail transport were calculated from the energy intensity of freight transport (Davis and Diegel, 2010) and GHG intensity of energy generation to yield an extra $3.5 \mathrm{~g} \mathrm{CO}_{2} / \mathrm{kg}$ feed.

\subsubsection{Diet purchase and production costs}

Diet cost was calculated based on the sum of off-farm feed purchase costs and on-farm feed production costs. Off-farm costs were based on current average commodity, feed, and byproduct prices (Horner and Sexten, 2014; USDA/ERS, 2012). On-farm costs were also based on current average commodity costs; however, it was assumed that onfarm production costs for feeds averaged $85 \%$ of purchase costs, reflecting the additional acquisition costs associated with off-farm feeds.

Table 2

Herd parameters and equations to calculate populations, weights, and productivity of cattle.

\begin{tabular}{|c|c|c|c|}
\hline Parameter & Units & Description & Value $^{a}$ \\
\hline RHA & $\mathrm{kg} / 10 \mathrm{~m}$ & Herd rolling average milk production & 9765 \\
\hline $\mathrm{AOC}$ & $\mathrm{m}$ & Age at Calving & $24^{\mathrm{b}}$ \\
\hline Dry & $\mathrm{m}$ & Months dry & 2 \\
\hline $\mathrm{CI}$ & $\mathrm{m}$ & Calving interval length & $12^{\mathrm{c}}$ \\
\hline AOW & $\mathrm{m}$ & Age at weaning & 2 \\
\hline $\mathrm{CR}_{\mathrm{c} 3[\mathrm{c} 4, \mathrm{c} 5]}$ & Calves/cow & Conception rate & $0.84[0.8,0.7]$ \\
\hline Heif & Calves/calf & Proportion of female calves & 0.51 \\
\hline Cull $_{\mathrm{c} 3,[\mathrm{c} 4, \mathrm{c} 5]}$ & Cows/cow & Proportion of cows culled & $0.22^{\mathrm{d}}$ \\
\hline $\mathrm{DL}_{\mathrm{c} 1,2[\mathrm{~b} 1,2]}$ & Calves/calf & Un-weaned calf death loss & 0.078 \\
\hline $\mathrm{DL}_{\mathrm{c} 1,12[\mathrm{~b} 1,12]}$ & Calves/calf & Weaned calf death loss & 0.018 \\
\hline BW & $\mathrm{kg}$ & Birth Weight & 50 \\
\hline MWc & $\mathrm{kg}$ & Mature weight of cows & 660 \\
\hline TW1 & $\%$ & Target percent of mature weight at weaning & 30 \\
\hline TW2 & $\%$ & Target percent of mature weigh at breeding & 55 \\
\hline TW3 & $\%$ & Target percent of mature weight at calving & 82 \\
\hline TW4 & $\%$ & Target percent of mature weight at $2^{\text {nd }}$ calving & 92 \\
\hline Eq. \# & \multicolumn{3}{|c|}{ Equation } \\
\hline (1) & & \multicolumn{2}{|c|}{$\operatorname{Pop}_{c 1,1}=\sum_{a}\left(\right.$ Pop $\left._{a, 5} * C R_{a}\right) *$ Heif } \\
\hline$(2)$ & & \multicolumn{2}{|c|}{$\operatorname{Pop}_{b 1,1}=\sum_{a}\left(\right.$ Pop $\left._{a, 5} * C R_{a}\right) *(1-$ Heif $)$} \\
\hline (3) & & \multirow{4}{*}{\multicolumn{2}{|c|}{$\begin{array}{l}\operatorname{Pop}_{a, m}=i f\left(m>1, \operatorname{Pop}_{a, m-1} *\left(1-D L_{a, m}\right), \operatorname{Pop}_{a-1,12} *\left(1-D L_{a, m}\right)\right) \\
\text { BW }_{c 1,1[b 1,1]}=B W \\
B W_{a, m}=i f\left(m>1, B W_{a, m-1}+A D G_{a, m}, B W_{a-1,12}+A D G_{a-1,12}\right)^{\mathrm{e}} \\
\text { Milk }=\left(\operatorname{Pop}_{c 3,1}+\operatorname{Pop}_{c 4,1}+\operatorname{Pop}_{c 5,1}\right) * \frac{R H A}{10} * \frac{12-D r y}{2} * \frac{12}{C I}\end{array}$}} \\
\hline (4) & & & \\
\hline (5) & & & \\
\hline (6) & & & \\
\hline
\end{tabular}

\footnotetext{
a When values are specific to an element of a set, the elements are defined in the parameter column and the values specific to those elements are defined using the same outline in the value section.

b Value represents recommended age at first calving.

c Value represents recommended calving interval, U.S. average is $13.2 \mathrm{~m}$.

d Average removal from operations (23.6\%) was multiplied by the proportion of cows going to market, auction or stockyard (76.2\%) or to a packer or slaughter plant (17.5\%).

e Average daily gains for pre-weaning $(0.97 \mathrm{~kg} / \mathrm{d})$, pre-breeding $(0.54 \mathrm{~kg} / \mathrm{d})$, and post-breeding $(0.65 \mathrm{~kg} / \mathrm{d})$ animals were calculated based on AOW, AOC and an $8 \mathrm{~m}$ gestation.
} 
Table 3

Nutritional and practical constraints employed in ration formulation.

\begin{tabular}{|c|c|c|c|}
\hline Parameter & Units & Description & Value \\
\hline $\mathrm{DMI}_{\mathrm{a}, \mathrm{m}, \mathrm{f}}$ & $\mathrm{kg} / \mathrm{d}$ & Dry matter intake of each feed & - \\
\hline Conc $_{n, \mathrm{f}}$ & mcal, g or mg/kg & Concentration of nutrients within the diet ${ }^{\mathrm{a}}$ & - \\
\hline $\operatorname{Req}_{\mathrm{a}, \mathrm{m}, \mathrm{n}}$ & mcal, g or $\mathrm{mg} / \mathrm{kg}$ & Nutrient requirement of cattle group by month ${ }^{\mathrm{b}}$ & - \\
\hline $\operatorname{MaxDM}_{\mathrm{a}, \mathrm{m}}$ & $\mathrm{kg} / \mathrm{d}$ & Maximum dry matter intake & - \\
\hline $\operatorname{UpLim}_{\mathrm{f}}$ & $\mathrm{kg} / \mathrm{kg}$ & Maximum proportion of feeds in the diet & - \\
\hline LowADF & $\mathrm{kg} / \mathrm{kg}$ & Lower limit of ADF percent & 15 \\
\hline Type $_{f}$ & - & Text descriptor for feed type (forage, concentrate, protein feed, byproduct, etc.) & - \\
\hline Eq. \# & \multicolumn{3}{|c|}{ Constraints } \\
\hline (7) & \multicolumn{3}{|c|}{$\sum_{f}\left(D M I_{a, m, f} * \operatorname{Conc}_{n, f}\right) \geq \operatorname{Re} q_{a, m, n}$} \\
\hline (8) & \multicolumn{3}{|c|}{$\sum_{f}\left(D M I_{a, m, f}\right) \leq M a x D M_{a, m}$} \\
\hline (9) & \multicolumn{3}{|c|}{$\frac{D M I_{a, m, f}}{\sum_{f}\left(D M I_{a, m, f}\right)} \leq \operatorname{UpLim}_{f}$} \\
\hline$(10)$ & \multicolumn{3}{|c|}{$\sum_{f o r}\left(D M I_{a, m, f} * \operatorname{Conc}_{N D F, f}\right)$} \\
\hline \multicolumn{4}{|c|}{$L o w A D F \leq \frac{j 01}{\sum_{f} D M I_{a, m, f}}$} \\
\hline
\end{tabular}

a Nutrient concentrations sourced from National Research Council (2001) feed library.

b Nutrient requirements calculated from National Research Council (2001) nutrient requirements of dairy cattle model.

\subsection{Model objectives and simulations}

A total of 28 scenarios were simulated. Five scenarios were modeled to assess the current opportunities to reduce environmental impact of dairy production. The baseline scenario minimized total feed cost given a set level of milk production (LC) because it was assumed that producers operate under least-cost management. Environmental impacts and diet cost of the LC scenario was compared to all other scenarios. Three single-objective scenarios were then conducted in which land use (LL10), water use (LW10) and GHG emissions (LG10) per kg of milk produced were minimized. The objective functions for these scenarios are listed in Table 6.
The outputted land use, water use, and GHG emissions were scaled by the population (Pop) of an animal group (a) within the model at any month $(m)$. Land use depended predominantly on crop yields (Yield). Water use depended on drinking (Drink) and irrigation (Irrig) water use. Greenhouse gases (methane, $\mathrm{CH} 4$; nitrous oxide, $\mathrm{N2O}$; and carbon dioxide, $\mathrm{CO} 2$ ) were converted to $\mathrm{CO}_{2}$-equivalents using 100 -yr warming potentials (IPCC, 2007). Single objective environmental scenarios often result in substantial tradeoffs between environmental output metrics (White et al., 2014). A multi-objective optimization (LA10) was conducted to simultaneously minimize land use, water use, and GHG emissions compared with the least-cost scenario land use (LCland), water use (LCh2o), and GHG emissions (LCghg). White

Table 4

Calculating environmental impact from cattle management.

\begin{tabular}{|c|c|c|c|c|}
\hline Parameter & Units & Description & Value & Reference \\
\hline $\mathrm{MY}_{\mathrm{a}, \mathrm{m}}$ & $\mathrm{kg} / \mathrm{d}$ & Milk yield/d & - & \\
\hline $\mathrm{DIM}_{\mathrm{a}, \mathrm{m}}$ & $\mathrm{d}$ & Days in milk & - & \\
\hline MCF & $\%$ & Methane conversion efficiency & See Table 5 & \\
\hline Bo & $\mathrm{m}^{3} \mathrm{CH}_{4} / \mathrm{kg} \mathrm{VS}$ & Maximum emission rate & 0.24 & IPCC (2006) \\
\hline EF3 & $\mathrm{kg}$ lost$/ \mathrm{kg}$ excreted & Direct emission factor & See Table 5 & IPCC (2006) \\
\hline EF4 & $\mathrm{kg}$ lost$/ \mathrm{kg}$ excreted & Volatilized emission factor & See Table 5 & IPCC (2006) \\
\hline EF5 & $\mathrm{kg}$ lost$/ \mathrm{kg}$ excreted & Leached emission factor & See Table 5 & IPCC (2006) \\
\hline HouseE & $\mathrm{kW} / \mathrm{animal}$ & Annual housing electricity expenditure & 326 & \\
\hline MilkE & $\mathrm{kW} /$ lactating cow & Annual milk cooling and storage energy expenditure & 247 & \\
\hline Temp & ${ }^{\circ} \mathrm{C}$ & Temperature & $20^{\mathrm{a}}$ & \\
\hline Eq. \# & Equation & & & Reference \\
\hline$(11)$ & \multicolumn{3}{|c|}{ Lactating : $\quad 2.303 * M Y_{a, m}+0.159 * D I M_{a, m}+70.1438 * \sum_{f}\left(D M I_{a, m, f} * n u t_{f, \prime^{\prime} p^{\prime}}\right)+0.193 * B W_{a, m}-56.632$} & \\
\hline$(12)$ & \multirow{2}{*}{\multicolumn{3}{|c|}{$\begin{array}{l}N 2 O_{a, m}=N E_{a, m} * E F 3 * \frac{44}{28}+N E_{a, m} * \frac{\text { FracGas }}{100} * E F 4 * \frac{44}{28}+N E_{a, m} * \frac{\text { FracLeach }}{100} * E F 5 * \frac{44}{28} \\
C H 4 m_{a, m}=\sum_{f}\left[\left(n u t_{f, \prime^{\prime} G E^{\prime}} *\left(\frac{1-n u t_{f^{\prime} \text { Dig }^{\prime}}}{100}\right)+\left(0.04 * n u t_{f,,^{\prime} G E^{\prime}}\right)\right) *\left(\frac{1-n u t_{f, A^{\prime} h^{\prime}}}{18.45}\right)\right] * B 0 * 0.067 * M C F\end{array}$}} & IPCC (2006) \\
\hline (13) & & & & IPCC (2006) \\
\hline$(14)$ & \multicolumn{4}{|c|}{$C H 4 e_{a, m}=3.41+0.511 * \sum_{f}\left(D M I_{a, m, f} * n u t_{f, N_{S C^{\prime}}}\right)+1.74 * \sum_{f}\left(D M I_{a, m, f} * n u t_{f, C^{\prime}}\right)+2.65 * \sum_{f}\left(D M I_{a, m, f} * n u t_{f, C^{\prime} C E^{\prime}}\right)$} \\
\hline$(15)$ & \multirow{2}{*}{\multicolumn{3}{|c|}{$\begin{array}{l}\mathrm{CH} 4_{a, m}=\mathrm{CH} 4 e_{a, m}+\mathrm{CH}_{4} m_{a, m} \\
\mathrm{CO} 2 \mathrm{i}=\text { HouseE } * \sum_{a} \text { Pop }_{a, m}+\operatorname{MilkE} *\left(\text { Pop }_{c 3,1}+\text { Pop }_{c 4,1}+\text { Pop }_{c 5,1}\right)\end{array}$}} & \\
\hline$(16)$ & & & & \\
\hline$(17)$ & \multicolumn{4}{|c|}{$H 2 O p=28.4 *\left(\left(\text { Pop }_{c 3,1}+\text { Pop }_{c 4,1}+\text { Pop }_{c 5,1}\right)^{*}(C I-D r y) * 30.5\right)$} \\
\hline (18) & \multicolumn{4}{|c|}{$H 2 O d=\left(-26.12+1.516 * T e m p+1.299 * M Y_{a, m}+0.058 * B W_{a, m}+0.406 * \sum_{f}\left(D M I_{a, m, f} * n u t_{f, N a^{\prime}}\right)\right.$} \\
\hline
\end{tabular}

\footnotetext{
a Although a constant temperature was used, the model had the ability to vary temperature monthly.
} 
Table 5

Emissions factors associated with manure management strategies and the proportion of operations in the U.S. handling manure with different strategies.

\begin{tabular}{lcllll}
\hline & $\%$ & EF3 $^{\mathrm{c}}$ & FracGas $^{\mathrm{c}}$ & FracLoss $^{\mathrm{c}}$ & MCF $^{\mathrm{c}}$ \\
\hline Operations with liquid manure $^{\mathrm{a}}$ & 58.0 & & & & - \\
Deep pit & 13.4 & 0.002 & 28 & 28 & 3 \\
Slurry tank & 16.7 & 0.005 & 40 & 40 & 26 \\
Slurry lagoon & 49.4 & 0.005 & 40 & 40 & 26 \\
Treated lagoon, not aerated & 11.8 & 0 & 35 & 77 & 78 \\
Aerated treated lagoon & 2.3 & 0.005 & & & 0 \\
Operations with solid manure & 42.0 & & & & - \\
Manure spreader & 43.0 & 0 & 7 & 22 & 0.5 \\
Manure pack & 19.6 & 0.07 & 20 & 40 & 3 \\
Outside manure stockpile & 19.0 & 0.005 & 30 & 40 & 4.0 \\
Dry lot & 9.8 & 0.02 & 20 & 30 & 1.5 \\
Inside manure stockpile & 3.9 & 0.005 & 30 & 40 & 4.0 \\
Composted & 1.5 & 0.0305 & & & 0.75 \\
Average & - & 0.0096 & 28 & 36 & 17.3
\end{tabular}

a Operations classified by USDA/APHIS (2007) as "other" or having a manure management system that did not fall into a category specified by IPCC (2006) were assumed to use a natural crust liquid storage system (equivalent to Slurry tank or lagoon).

b Operations classified by USDA/APHIS (2007) as "other" or having a manure management system that did not fall into a category specified by IPCC (2006) were assumed to use a manure spreader.

c Abbreviations reflect input variables used in Table 5.

and Brady (2014) highlighted the relationship between allowable diet cost increases and opportunities to reduce environmental impact. To simulate a realistic budget constraint, the LW10, LL10 and LG10 scenarios were constrained to allow a $10 \%$ increase in cost over the LC scenario. To better understand the trade-offs between cost and environmental impact reduction, a series of 8 more scenarios were conducted minimizing land use (LL1; LL5), water use (LW1; LW5), GHG emissions (LG1; LG5) or all environmental impact metrics (LA1; LA5), with the additional constraint that diet cost could not exceed a $1 \%$ or $5 \%$ increase over the cost in the LC scenario. The cost increase is indicated in the scenario abbreviation by the number. For example, LA1 allowed a $1 \%$ increase in cost and LA5 allowed a 5\% increase.

To identify how different animal nutrition research avenues might help to minimize land use, water use or GHG emissions from U.S. dairy cattle production systems, scenarios minimizing all metrics $\left(L_{x}\right)$ were compared to scenarios with improved energy $\left(L_{A} E_{x}\right)$, protein $\left(\operatorname{LAP}_{\mathrm{x}}\right)$ and energy and protein $\left(\mathrm{LAEP}_{\mathrm{x}}\right)$ efficiencies. Allowable cost increases ( $\mathrm{X}$ in the previous abbreviations) were $1,5,10,15$ and $20 \%$ above the least cost scenario resulting in 20 scenarios for comparison. Energy-use efficiency and protein-use efficiency were increased by $15 \%$ either individually or collectively. Improved energy-use efficiency was modeled as a 15\% decrease in the allometric energy constant used to calculate maintenance energy requirement of cattle within the system. A $15 \%$ improvement in protein-use efficiency was modeled as a $15 \%$ decrease in maintenance metabolizable protein requirements.
These metrics were selected because they may represent targets that can be selected for genetically or manipulated nutritionally. Energy balance studies show moderate variability in heat production as a function of metabolizable energy (ME) intake (Moe, 1981). Animals with low residual heat production will lose less heat per unit of ME intake than the average animal in the population. If markers can be identified that correlate with these animals that produce less residual heat, there may be opportunities to select for animals that have a lower maintenance requirement, thereby diluting maintenance of the dairy population. Dilution of maintenance is key to improving environmental impact (Capper and Bauman, 2013) and has positive benefits on economic viability of livestock operations (White and Capper, 2013).

In low-protein diets with balanced amino-acid composition, there is opportunity to reduce total protein intake without compromising milk production (Lee et al., 2012). Although this does not directly imply a reduced maintenance requirement for protein, maintenance protein requirements are currently based on broad protein indices (crude, metabolizable, etc.) and thus likely over-predict maintenance requirements based on amino acids. Better characterization of dairy cattle amino acid requirements may help to reduce total protein intake and improve nitrogen use efficiency in dairy cattle.

\section{Results and discussion}

\subsection{Evaluating baseline performance}

Environmental output metrics from LC are compared to ranges established by previous literature in Table 7. A summary of the growing (Fig. 2) and lactating diets (Fig. 3) used are presented diagrammatically. The baseline lactation diet was slightly less expensive ( $\$ 2.80 / \mathrm{d}$ to $\$ 4.10 / \mathrm{d}$ ) than the $\$ 4.78 / \mathrm{d}$ estimate given in AmaralPhillips (2010), likely because grain prices in the U.S. have decreased since 2010. Lactating cow enteric $\mathrm{CH}_{4}$ emissions ( 220 to $440 \mathrm{~g} / \mathrm{d}$ ) represented the range given in previously published literature (Holter and Young, 1992; Sauer et al., 1998) very well. Enteric $\mathrm{CH}_{4}$ emissions on calves, bulls and growing replacements animals are infrequently reported; however, Johnson and Johnson (1995) suggest a range of 2 to $12 \%$ of gross energy intake is possible. The emissions from these cattle groups ranged from 5 to $6 \%$ of gross energy emissions, which was well within the established range and a good representation of cattle on forage diets. Manure $\mathrm{N}_{2} \mathrm{O}$ and $\mathrm{CH}_{4}$ emissions reported by Amon et al. (2001) ranged from 0.14 to $1.19 \mathrm{~g} / \mathrm{d}$ and 170 to $218 \mathrm{~g} / \mathrm{d}$, respectively. The manure emissions modeled in this study agreed with these ranges.

The LC scenario predicted $0.70 \mathrm{~kg} \mathrm{CO}$-e $/ \mathrm{kg}$ milk. Global estimates of milk carbon footprint are moderately variable (De Vries and De Boer, 2010). Estimates GHG emissions from U.S. milk production systems typically range between 0.53 (Rotz et al., 2010) and 1.23 (Thoma et al., 2013a). Dalgaard et al. (2014) estimated values of 1.05 and

Table 6

Objective functions and names of related simulations.a

\begin{tabular}{|c|c|c|}
\hline Simulation $^{\mathrm{a}}$ & Eq. \# & Objective function \\
\hline Minimizing cost & (19) & Min : Cost $=\sum_{f, a}\left(D_{M} I_{f} * F P_{f} *\right.$ Pop $_{a} *$ Days $\left._{a}\right)$ \\
\hline Minimizing water use (L/kg milk) & $(20)$ & $\operatorname{Min}: H 2 O=\frac{\sum_{a, m}\left(\operatorname{Drink}_{a, m} * \operatorname{Pop}_{a, m} * \text { Days }_{a, m}\right)+\sum_{a, m, f}\left(\operatorname{Irrig}_{f} * \operatorname{DMI}_{a, m, f} * \text { Pop }_{a, m} * \text { Days }_{a, m}\right)}{\text { Milk }}$ \\
\hline Minimizing land use $\left(\mathrm{m}^{3} / \mathrm{kg}\right.$ milk) & $(21)$ & Min $:$ Land $=\frac{\sum_{f, a, m}\left(\sum_{a, m}\left(\text { DMI }_{a, m, f} * \text { Pop }_{a, m} * \text { Days }_{a, m}\right) / \text { Yield }_{f}\right)}{\text { Milk }}$ \\
\hline Minimizing greenhouse gas emissions $\left(\mathrm{CO}_{2} \mathrm{e} / \mathrm{kg}\right.$ milk $)$ & $(22)$ & Min : GHG $=\frac{25 * \sum_{a, m}\left(\mathrm{CH}_{a, m} * \text { Pop }_{a, m}^{\text {Milk }} * \text { Days }_{a, m}\right)+298 * \sum_{a, m}\left(\mathrm{~N}^{2} \mathrm{O}_{a, m} * \text { Pop }_{a, m} * \text { Days }_{a, m}\right)+\mathrm{CO} 2}{}$ \\
\hline $\begin{array}{l}\text { Minimizing water use ( } \mathrm{L} / \mathrm{kg} \text { milk), land use }\left(\mathrm{m}^{3} / \mathrm{kg} \text { milk), and greenhouse gas }\right. \\
\text { emissions }\left(\mathrm{CO}_{2} \mathrm{e} / \mathrm{kg} \text { milk). }\right.\end{array}$ & (23) & $\begin{array}{l}\text { Min : Obj } \\
\text { Obj }=(\text { Land-LCland }) / \text { LCland } \\
\text { Obj }=(\text { H20-LCh2o }) / \text { LCh } 20 \\
\text { Obj }=(\text { GHG }- \text { LCghg }) / \text { LCghg }\end{array}$ \\
\hline
\end{tabular}

\footnotetext{
a Simulations included minimizing cost (LC), minimizing water use (LW), minimizing land use (LL), minimizing greenhouse gas emissions (LG), or minimizing land use, water use and
} greenhouse gas emissions (LA). 
Table 7

Comparison of predicted environmental impact metrics with literature measurements.

\begin{tabular}{|c|c|c|c|c|c|}
\hline Metric $^{1}$ & Population & Value & Literature range & Units & Citations \\
\hline \multirow[t]{2}{*}{$\mathrm{CH}_{4} \mathrm{e}$} & Lactating Cows & 220 to 440 & 208 to 406 & $\mathrm{~g} / \mathrm{d}$ & Holter and Young (1992), Sauer et al. (1998) \\
\hline & Other cattle & 5.0 to 6.0 & 2 to 12 & $\% \mathrm{GEI}^{2}$ & Johnson and Johnson (1995) \\
\hline $\mathrm{CH}_{4} \mathrm{~m}$ & Cows & 176 to 210 & 170 to 218 & $\mathrm{~g} / \mathrm{d}$ & Amon et al. (2001) \\
\hline $\mathrm{N}_{2} \mathrm{Om}$ & Cows & 0.08 to 1.67 & 0.14 to 1.19 & $\mathrm{~g} / \mathrm{d}$ & Amon et al. (2001) \\
\hline Cost & Lactation diet & $\$ 2.80$ to $\$ 4.10$ & $\$ 4.78$ & $\$ / d$ & Amaral-Phillips (2010) \\
\hline Land & Production system & 1.22 & 1.62 & $\mathrm{~m}^{2} / \mathrm{kg}$ & Capper et al. (2009) \\
\hline $\mathrm{H}_{2} \mathrm{O}$ & Production system & 1.10 & 0.92 to 60 & $\mathrm{~m}^{3} / \mathrm{kg}$ & Sultana et al. (2015) and Mekonnen and Hoekstra (2010) \\
\hline GHG & Production system & 0.70 & 0.53 to 1.23 & $\mathrm{~kg} \mathrm{CO}$-e/kg & Rotz et al. (2010) and Thoma et al. (2013a) \\
\hline
\end{tabular}

1 Metrics are as defined by equations in Tables 2, 3 and 4

2 Gross energy intake (GEI).

3 Only the blue water footprint was sourced from Mekonnen and Hoekstra (2010).

$1.80 \mathrm{~kg} \mathrm{CO}-\mathrm{e} / \mathrm{kg}$ but land use change was included in these emissions calculations and contributed to the higher values. The elevated baseline GHG emissions identified in this study may be a result of modeling different efficiencies within the farm system. The range in GHG emissions estimated from surveyed farm systems in Thoma et al. (2013a) varied from $0.75 \mathrm{~kg} \mathrm{CO}$-e/ $\mathrm{kg}$ to greater than $2.5 \mathrm{~kg} \mathrm{CO}_{2}-\mathrm{e} / \mathrm{kg}$, demonstrating substantial variability in GHG emissions per kg product. Considering this variability, the GHG emissions estimated within this study conform well to established ranges.

Land use in the LC scenario was estimated at $1.22 \mathrm{~m}^{2} / \mathrm{kg}$ milk. Previous studies have estimated land use at $1.62 \mathrm{~m}^{2}$ (Capper et al., 2009) which was close to the value estimated in this study and to the values reported for an average New Zealand farm (Basset-Mens et al., 2009) or a commercial dairy in the Netherlands (Thomassen et al., 2008). Land use can vary substantially depending on the feeding system. For example, Irish farms utilized between 0.64 and $0.84 \mathrm{~m}^{2}$ per kg milk produced (Lovett et al., 2006). Similarly, Cederberg and Mattsson (2000) identified that the land use of Swedish conventional $\left(1.93 \mathrm{~m}^{2} / \mathrm{kg}\right)$ and organic $\left(3.46 \mathrm{~m}^{2} / \mathrm{kg}\right)$ differed substantially. The LC lactating cow diets relied heavily on byproduct feeds. As such, it is not surprising that the land use in this study was slightly lower than those identified previously for U.S. systems (Capper et al., 2009).

Water required to produce milk also varied substantially depending on diet. Mekonnen and Hoekstra (2010) developed a water use accounting method to fully account for the green, gray and blue water required to produce animal-derived food products. In general, this method tends to predict higher water use than diet optimization models (White and Brady, 2014) likely because additional water requirements are allocated to livestock products. Global average dairy water use has been estimated at $1.83 \mathrm{~m}^{3} / \mathrm{kg}$ with a range of 0.74 to $5.6 \mathrm{~m}^{3} / \mathrm{kg}$ (Sultana et al., 2015). The baseline water use value in the present study was well within this range $\left(1.10 \mathrm{~m}^{3} / \mathrm{kg}\right)$ but substantially lower than the values of Mekonnen and Hoekstra (2010).

\subsection{Opportunities to minimize land, water or greenhouse gas emissions}

Reductions in land use, water use, and GHG emissions are presented in Fig. 4. Land required to produce $1 \mathrm{~kg}$ of milk decreased 32, 62 or $75 \%$ with cost increases of 1,5 or $10 \%$ compared to LC. When land use was targeted, simultaneous reductions in water and GHG emissions were realized. The lack of tradeoffs between land, water and GHG emissions was not expected. Previous environmental multi-objective optimization exercises for beef (White et al., 2014) and dairy cattle (Tozer and Stokes, 2001) reported substantial competition between environmental metrics. The additional feeds available in this analysis may be one reason why the trade-offs between land and water observed in White et al. (2014) did not appear. Additionally, several of the feeds available in the analysis are byproducts. Because the land, water and carbon resources for these products are allocated between a primary product and feed byproducts, the environmental intensity is often lower than nutritionally-comparable primary feed products.

Under a tight budget constraint (LL1), dairy diets relied primarily on potato byproducts, wheat grain, straw and middlings. As the budget constraint relaxed (LL5 and LL10), potato byproducts were swapped

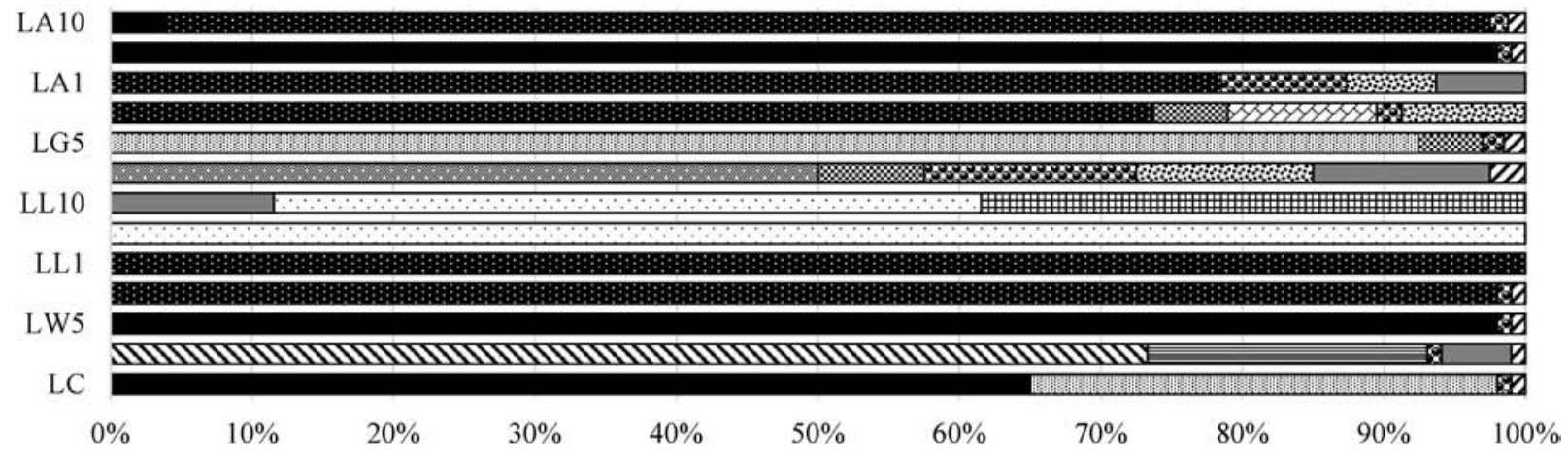

\$Alfalfa meal
$\boxplus$ On-Farm Corn Silage
$\square$ On-Farm Grass Silage
Sunflower Meal
Vegetable Oil

Legume Silage
目Linseed Meal
$\square$ Potato Byproduct Meal
Wheat Middlings
$\square$ Meat and Bone Meal

$\square$ Molasses
日Grass Pasture
\&ice bran
Dicalcium Phosphate
$\square$ Vitamin Premix

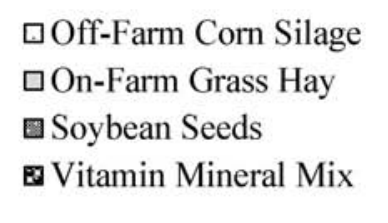

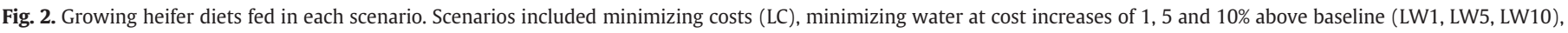

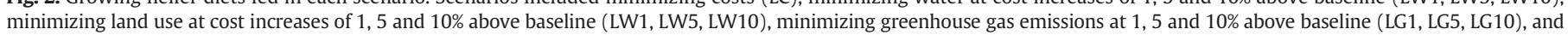
minimizing land use, water use and greenhouse gas emissions at 1, 5 and 10\% cost increases above baseline (LA1, LA5, LA10). 


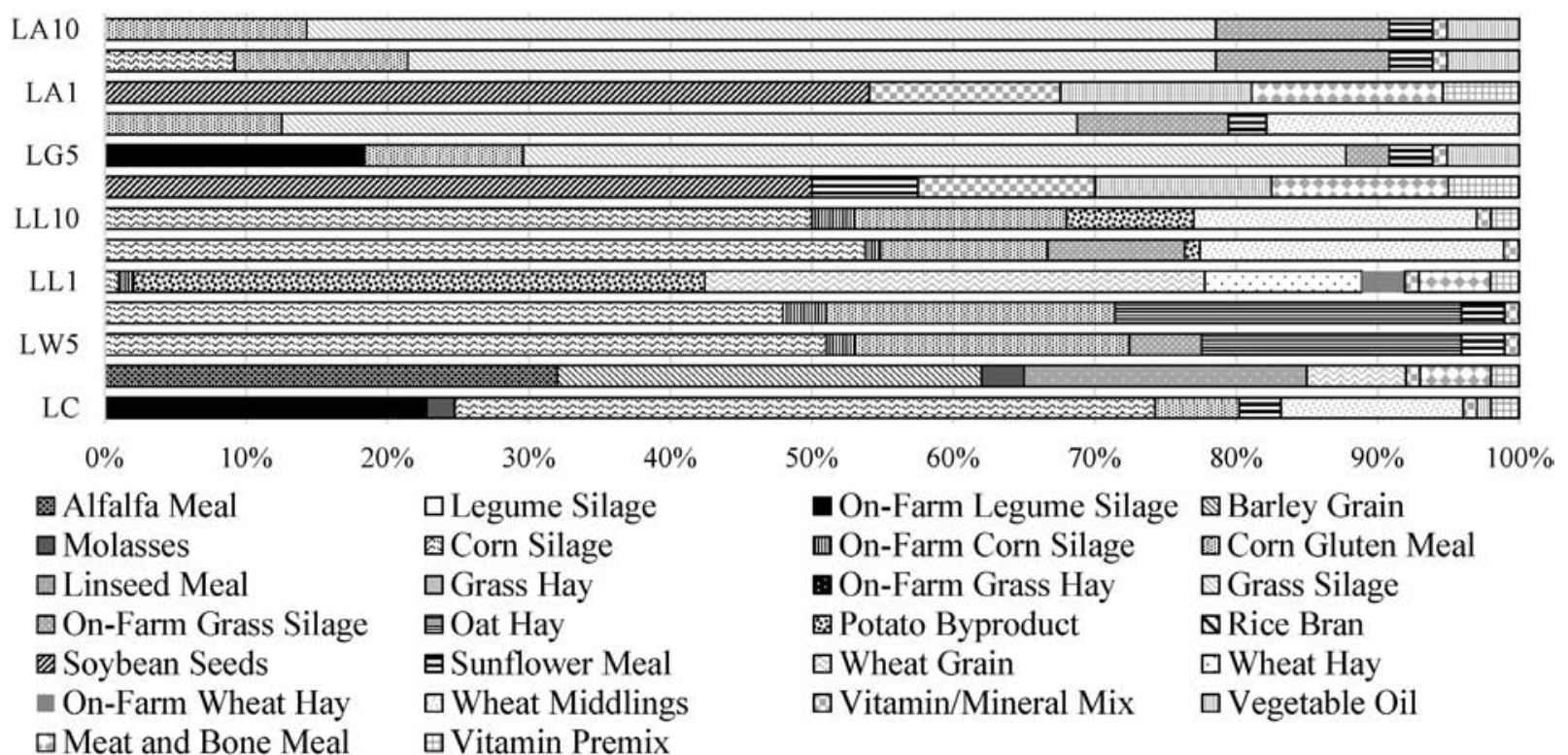

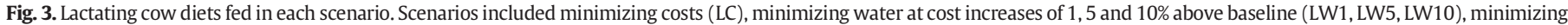

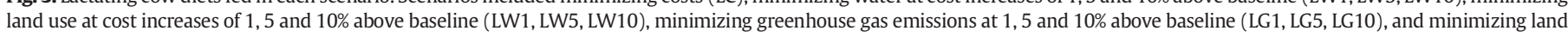
use, water use and greenhouse gas emissions at 1, 5 and 10\% cost increases above baseline (LA1, LA5, LA10).

for maize silage, maize gluten meal, grass silage, and increasing concentrations of wheat middlings were used. Growing cattle diets under a tight budget constraint employed grass pasture and switched to maize silage (LL5), supplemented with molasses (LL10) as the budget constraint relaxed.

Changes in lactating cow emissions were similar for LL1, LL5 and LL10. Individual enteric $\mathrm{CH}_{4}$ emissions ranged from $420 \mathrm{~g} / \mathrm{d}$ (LL5) to $440 \mathrm{~g} / \mathrm{d}$ (LL1) and were not markedly different from enteric emissions in LC. Lactating cow manure $\mathrm{CH}_{4}$ also was similar between land minimizing scenarios and did not differ substantially from LC. Manure $\mathrm{N}_{2} \mathrm{O}$ attributable to lactating cows ranged from $1.18 \mathrm{~g} / \mathrm{d}$ (LL1) to $1.58 \mathrm{~g} / \mathrm{d}$ (LL10). At a low budget constraint, $\mathrm{N}_{2} \mathrm{O}$ emissions were lower than those with LC. As the budget increased, emissions also increased to eventually exceed the baseline levels. Growing-cattle enteric and manure $\mathrm{CH}_{4}$ emissions decreased as the budget constraint increased but manure $\mathrm{N}_{2} \mathrm{O}$ emissions also increased.

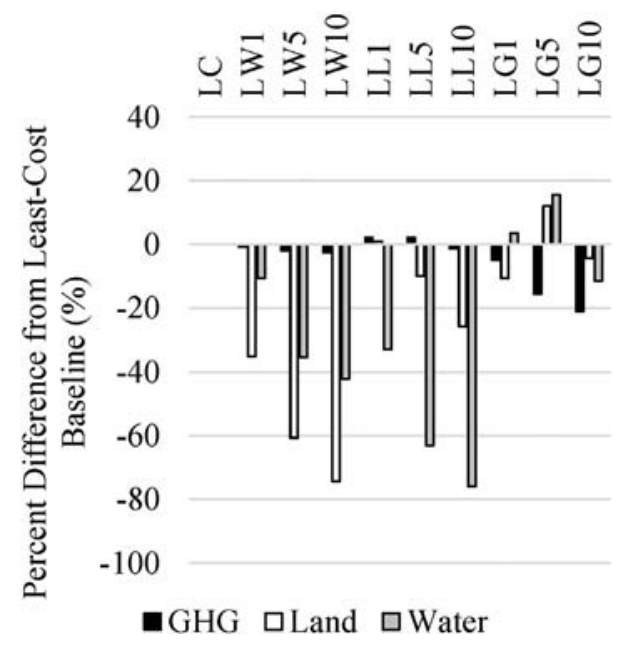

Fig. 4. Greenhouse gas, land use, and water use reductions achieved during scenarios with current nutrient requirements. Scenarios minimizing water $\left(\operatorname{LW}_{x}\right)$, land $\left(L_{x}\right)$, and greenhouse gas emissions $\left(L G_{x}\right)$ individually or simultaneously $\left(L_{x}\right)$. Cost increases (X) above the least cost baseline scenario (LC) were set a 1,5 or $10 \%$. Negative values indicate an improvement compared with the LC scenario, positive values indicate and increase in environmental impact compared with the LC scenario.
Water use, like land use, was readily minimized. Land use in the LW1 scenario was reduced 34\% compared to that in LC. As the budget constrain increased, opportunities to decease water use increased (LW5: 60\%; LW10: 73\%). Water is an economically important commodity on dairy farms and reduced water availability can compromise farm profitability (Ho et al., 2014). The substantial increase in affordable water use reductions achievable with increased budget flexibility identified here supports the expense of reducing water use.

Water-reducing diets varied with available cost increases. When a $1 \%$ increase was allowable, heifers were fed a diet composed of alfalfa meal, linseed meal and alfalfa pasture. Lactating cow diets also relied on alfalfa meal and linseed meal with the addition of barley grain, wheat grain, and meat and bone meal. In LW5 and LW10, heifer diets transitioned to alfalfa silage and to grass pasture, respectively. Growing cattle $\mathrm{N}_{2} \mathrm{O}$ emissions were reduced by $7 \%$ compared to those in $\mathrm{LC}$ and $\mathrm{CH}_{4}$ did not change substantially. Lactating cow enteric $\mathrm{CH}_{4}$ were reduced 5. Manure $\mathrm{CH}_{4}$ and manure $\mathrm{N}_{2} \mathrm{O}$ increased 4 and 23\%, respectively.

Minimizing GHG emissions was less efficient than land or water. In LG1, LG5 and LG10, 4, 15 and 20\% reductions in GHG emissions were achieved, respectively. Targeting the reduction of GHG emissions from dairy production tended to result in increased water use. Analysis of individual animal emissions suggests that reducing $\mathrm{N}_{2} \mathrm{O}$ emissions was the primary strategy at a low budget constraint and targeting $\mathrm{CH}_{4}$ became more important as the budget constraint relaxed. Mc Geough et al. (2012) found that reducing lactating cow $\mathrm{CH}_{4}$ emissions was the most promising method of reducing GHG emissions for dairy production. The focus on $\mathrm{CH}_{4}$ emissions at more flexible budget constraints supports this finding; however, the focus on $\mathrm{N}_{2} \mathrm{O}$ emissions at less flexible budget constraints suggests that improving $\mathrm{N}$ efficiency may be a more viable option for producers hesitant to increase operating costs.

Diets fed to lactating cattle in the LG scenarios relied on legume silage, molasses, maize silage, soybean, sunflower oil, and wheat middlings. At a low budget constraint, grass hay was used in place of legume silage, and rice bran and alfalfa meal were important diet components. Growing cattle diets relied on grass hay, potato byproduct meal, rice bran and soybean when allowable cost increases were low. As the budget constraint relaxed, legume silage and maize silage were relied upon more heavily. 
The results of this simulation depend on the assumption that different feed ingredients would always be available to the operation in question. In practice, feed ingredient availability varies by region and season, among other factors. Future work should attempt to better account for this spatial heterogeneity.

\subsection{Opportunities to minimize land, water and greenhouse gas emissions}

Greenhouse gas mitigation has been a primary focus of environmental research in recent years (Beauchemin et al., 2008; De Boer et al., 2011; Del Prado et al., 2013; FAO, 2013). Although mitigation of GHG emissions is an important goal, the tradeoffs between GHG emissions and other environmental metrics (White et al., 2014) suggest that policies oriented at improving GHG efficiency should concurrently consider water and land use. In LA1, water and GHG reductions of 3.4\% were achievable and the diet required to minimize them simultaneously allowed for a $17 \%$ reduction in land use. This difference in output efficiency occasionally occurs in multi-objective optimization scenarios and is a result of highly competitive diet options, expensive feeding solutions and strict budget constraints. More frequently, as observed in LA5 and LA10, equivalent reductions in all metrics are observed. Here, a 5\% cost increase helped reduce land, water and GHG emissions by $12.3 \%$, and a $10 \%$ cost increase reduced environmental metrics by $19.1 \%$. The relationship between land use, water use, and GHG emissions improvement and diet cost demonstrated diminishing returns to increasing costs.

The dietary strategy at LA1 differed from LA5 and LA10. In LA1 lactating cow diets relied on grass hay, rice bran, soybean, sunflower and vegetable oils, and meat and bone meal. This diet reduced enteric $\mathrm{CH}_{4}$ by 9.3\% and increased manure $\mathrm{CH}_{4}$ and $\mathrm{N}_{2} \mathrm{O}$ emissions by 2.3 and $8.3 \%$, respectively. Growing-cattle diets in LA1 relied on the same feedstuffs used in lactating cow diets with the substitution of grass pasture rather than grass hay. Like the diet for lactating cows, this diet offset emission changes (enteric: $-18.9 \%$; manure $\mathrm{CH}_{4}$ : $+4.8 \%$; manure $\mathrm{N}_{2} \mathrm{O}:+8.3$ ).

\subsection{Impacts of animal nutrition research}

At strict budget constraints ( $1 \%$ cost increase) improving energy efficiency substantially improved opportunities to reduce land use, water use, and GHG emissions (Fig. 5). Water and GHG reductions observed in LA1 were 3.4\%, only a fraction of those achievable in LAE1 (21.5\%). Improving protein-use efficiency was similarly effective and

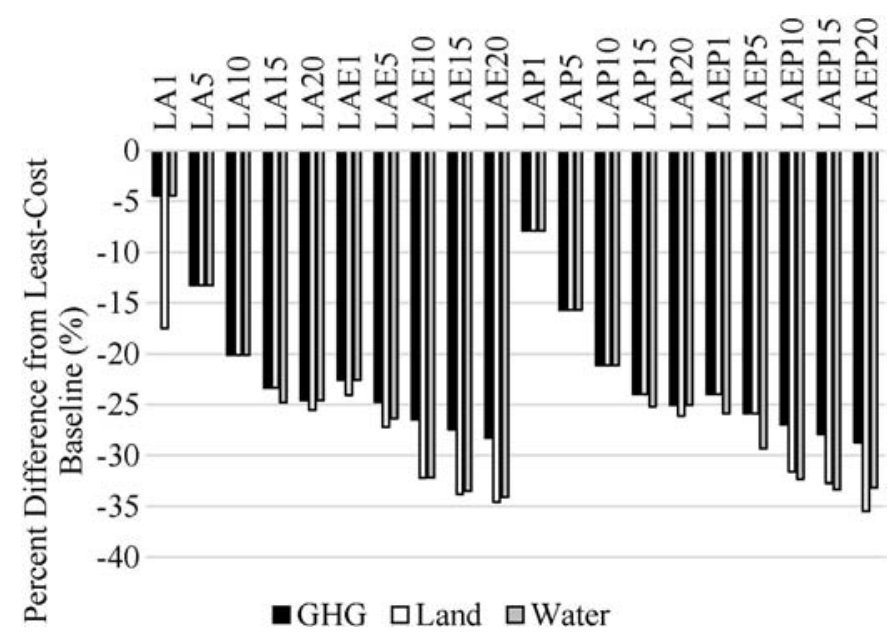

Fig. 5. Environmental impact reductions achievable with current nutrient requirements $\left(L A_{x}\right)$ or with reduced energy $\left(L_{A} E_{x}\right)$, protein $\left(L A P_{x}\right)$ or energy and protein $\left(\operatorname{LAEP}_{x}\right)$ requirements with cost increases above baseline $(X)$ set at $1,5,10,15$ or $20 \%$ above the least cost baseline. enabled a $6.9 \%$ reduction in land use, water use, and GHG emissions. If both energy- and protein-use efficiency were improved by $15 \%$, the environmental impact reduction attainable with at a $1 \%$ cost increase was 7.2 times greater than in the LC scenario (14.7\% compared with $5.9 \%$ ). Previous studies on beef cattle (Cooprider et al., 2011; White and Capper, 2013), aquaculture (Amirkolaie, 2011; Besson et al., 2014), dairy cattle (Cederberg and Mattsson, 2000), laying hens (Pelletier et al., 2014), broilers (Pelletier, 2008) and swine (Dourmad et al., 2014) have linked improved efficiency with reduced GHG emissions per unit of product.

The results in this study and previous studies worldwide and across species suggest that reducing the feed required to produce an equivalent weight of product is a primary and essential strategy to mitigate GHG emissions or resource use in livestock production systems. Previous dairy studies have identified that GHG emissions is reduced when milk production, fertility or longevity are increased (Bell et al., 2011). In a comparison of Swedish and New Zealand dairy production systems, feed efficiency was identified as one of the most important parameters controlling GHG-emissions intensity (Cederberg et al., 2009); the consequence of reducing feed efficiency by $10 \%$ was a 6.6 to $8.5 \%$ increase in GHG emissions. In a survey of Italian, Danish and German dairies, feed efficiency was identified as a primary factor contributing to environmental impact and was negatively correlated with GHG emissions, acidification and eutrophication potential (Guerci et al., 2013). In the U.S., substantial farm-to-farm variability in GHG emission intensity was explained by differences in feed efficiency (Thoma et al., 2010).

Several promising avenues of research exist that may help realize notable improvements in dairy feed efficiency. Initial studies suggest that obtaining genomic breeding values for cow DMI may be a promising strategy to improve feed efficiency and reduce GHG emissions (de Haas et al., 2014). Although measuring individual cow DMI presents practical concerns on-farm, genetic variation in DMI can be primarily explained by production traits that are readily measured such as body weight, growth and milk yield (Berry and Crowley, 2013). The environmental benefits from improving energy-use efficiency calculated in this study could be achieved by careful selection of more efficient cows. Another strategy to improve feed efficiency is to improve $\mathrm{N}$-use efficiency (Jonker et al., 2002). Feeding cows to amino acid requirements may be a promising way to improve N-use efficiency (Lee et al., 2012). Predicting amino-acid requirements in lactating dairy cows remains challenging and thus improved understanding of amino-acid utilization is essential to this research effort (Arriola Apelo et al., 2014; Lapierre et al., 2014; Patton et al., 2014). Optimizing milk protein synthesis is complicated by interactions between amino-acid balance, energy content and carbohydrate availability (Rius et al., 2010a,b), and thus concurrent focus on energy and protein efficiency may be a more productive research focus. Additionally, results of this analysis demonstrate that the benefits of simultaneous improvements in energy and protein efficiency are substantial and greater than would be expected if the improvements were additive.

As cost increases above LC were allowed to increase, the relative economic benefits of improving energy- or protein-use efficiency decreased. Given that dairy producers often operate on tight profit margins and the long-term viability of their businesses rely on ensuring costs are kept to a minimum, improving energy- and protein-use efficiency should be a primary objective of dairy producers interested in reducing land use, water use, and GHG emissions. To estimate the cost required to reducing these environmental impacts, continuous curvilinear relationships were derived from the achievable GHG emissions, land use, and water use reductions predicted as the budget constraint relaxed (Fig. 5). The increased cost required to reduce environmental impact by $25 \%$ was $42 \%$ lower in LAE than in LA and $31 \%$ lower in LAP than in LA. Improving energy- and protein-use efficiency had remarkable benefits from an economic perspective. Cost required to achieve a $25 \%$ reduction in land use, water use, and GHG emissions was $81 \%$ lower in LAEP than in LA. Collectively, these data suggest that animal-nutrition 
research oriented at improving energy- and protein-use efficiency is vital to efforts to improve GHG emissions and reduce resource use in dairy production systems.

\section{Conclusions}

The diet optimization model presented in this study is a unique approach to identifying nutritional management strategies to decrease GHG emissions, land use, and water use of dairy production systems. Given currently available feedstuffs, substantial opportunity exists to decrease land use, water use, and GHG emissions of dairy production systems with nominal on-farm cost increases. Evaluation of the environmental benefits of future animal-nutrition research demonstrated that improved energy and protein efficiency greatly reduced the cost of achieving targeted reductions in land use, water use, and GHG emissions.

Supplementary data to this article can be found online at http://dx. doi.org/10.1016/j.agsy.2016.03.013.

\section{Acknowledgements}

The author would like to acknowledge the data and resources available at the National Animal Nutrition Program website (http://nanpnrsp-9.org) and the animal nutrition research support efforts of the National Animal Nutrition Program for the contribution to and role in this work.

\section{References}

Amaral-Phillips, D., 2010. What does it cost to feed your cows? Cooperative extension service. University of Kentucky URL (http://www.uky.edu/Ag/AnimalSciences/dairy/ newsletters/2011Special/dap0110.pdf).

Amirkolaie, A.K., 2011. Reduction in the environmental impact of waste discharged by fish farms through feed and feeding. Rev. Aquac. 3, 19-26.

Amon, B., Amon, T., Boxberger, J., Alt, C., 2001. Emissions of $\mathrm{NH}_{3}, \mathrm{~N}_{2} \mathrm{O}$ and $\mathrm{CH}_{4}$ from dairy cows housed in a farmyard manure tying stall (housing, manure storage, manure spreading). Nutr. Cycl. Agroecosyst. 60, 103-113.

Arriola Apelo, S., Knapp, J., Hanigan, M., 2014. Invited review: current representation and future trends of predicting amino acid utilization in the lactating dairy cow. J. Dairy Sci.

ASAE, 2005. Manure production and characteristics (ASAE D384.2 MAR20050). American Society of Agricultural Engineers, St. Joseph, MI, USA.

Basset-Mens, C., Ledgard, S., Boyes, M., 2009. Eco-efficiency of intensification scenarios for milk production in New Zealand. Ecol. Econ. 68, 1615-1625.

Beauchemin, K.A., Kreuzer, M., O'Mara, F., McAllister, T.A., 2008. Nutritional management for enteric methane abatement: a review. Aust. J. Exp. Agric. 48, 21-27.

Bell, M., Wall, E., Russell, G., Simm, G., Stott, A., 2011. The effect of improving cow productivity, fertility, and longevity on the global warming potential of dairy systems. J. Dairy Sci. 94, 3662-3678.

Berry, D., Crowley, J., 2013. Cell biology symposium: genetics of feed efficiency in dairy and beef cattle. J. Anim. Sci. 91, 1594-1613.

Besson, M., Komen, H., Vandeputte, M., Aubin, J., De Boer, I., Van Arendonk, J., 2014. Economic and environmental impacts of improving growth rate and feed efficiency in fish farming depend on nitrogen and density limitation. 10th World Congress of Genetics Applied to Livestock Production, August 17-22, 2014. Vancouver, Canada.

Beukes, P., Palliser, C., Macdonald, K., Lancaster, J., Levy, G., Thorrold, B., Wastney, M., 2008. Evaluation of a whole-farm model for pasture-based dairy systems. J. Dairy Sci. 91, 2353-2360

Burek, J., Thoma, G., Popp, J., Maxwell, C., Ulrich, R., 2014. Developing environmental footprint, cost and nutrient database of the US animal feed ingredients. In: Schenck, R. Huizenga, D. (Eds.), 9th International Conference on life Cycle Assessment in the Agri-Food Sector (LCA Food 2014). American Center fo Life Cycle Assessment, San Francisco, CA, pp. 185-193.

Capper, J.L., Bauman, D.E., 2013. The role of productivity in improving the environmental sustainability of ruminant production systems. Annu. Rev. Anim. Biosci. 1, 469-489.

Capper, J.L., Castaneda-Gutierrez, E., Cady, R.A., Bauman, D.E., 2008. The environmental impact of recombinant bovine somatotropin (rbST) use in dairy production. Proc. Natl. Acad. Sci. U. S. A. 105, 9668-9673.

Capper, J.L., Cady, R.A., Bauman, D.E., 2009. The environmental impact of dairy production: 1944 compared with 2007. J. Anim. Sci. 87, 2160-2167.

Cederberg, C., Mattsson, B., 2000. Life cycle assessment of milk production-a comparison of conventional and organic farming. J. Clean. Prod. 8, 49-60.

Cederberg, C., Meyer, D., Flysjö, A., 2009. Life cycle inventory of greenhouse gas emissions and use of land and energy in Brazilian beef production. SIK-Institutet för livsmedel och bioteknik.
Cooprider, K., Mitloehner, F., Famula, T., Kebreab, E., Zhao, Y., Van Eenennaam, A., 2011. Feedlot efficiency implications on greenhouse gas emissions and sustainability. J. Anim. Sci. 89, 2643-2656.

Crosson, P., Shalloo, L., O’Brien, D., Lanigan, G., Foley, P., Boland, T., Kenny, D., 2011. A review of whole farm systems models of greenhouse gas emissions from beef and dairy cattle production systems. Anim. Feed Sci. Technol. 166, 29-45.

Dalgaard, R., Schmidt, J., Flysjö, A., 2014. Generic model for calculating carbon footprint of milk using four different life cycle assessment modelling approaches. J. Clean. Prod. 73, 146-153.

Davis, S.C., Diegel, S.W., 2010. United States. Dept. of Energy. Office of Energy Efficiency and Renewable Energy., United States. Dept. of Energy. Office of Energy Efficiency and Renewable Energy. Office of Planning Budget Formulation and Analysis., Oak Ridge National Laboratory. Transportation Energy Data Book, 23rd ed. Oak Ridge National Laboratory, Oak Ridge, Tenn.

De Boer, I., Cederberg, C., Eady, S., Gollnow, S., Kristensen, T., Macleod, M., Meul, M., Nemecek, T., Phong, L., Thoma, G., 2011. Greenhouse gas mitigation in animal produc tion: towards an integrated life cycle sustainability assessment. Curr. Opin. Environ. Sustain. 3, 423-431.

de Haas, Y., Pryce, J., Berry, D., Veerkamp, R., 2014. Genetic and genomic solutions to improve feed efficiency and reduce environmental impact of dairy cattle. Proceedings, 10th World Congress of Genetics Applied to Livestock Production.

De Vries, M., De Boer, I., 2010. Comparing environmental impacts for livestock products: a review of life cycle assessments. Livestock Sci. 128, 1-11.

del Prado, A., Shepherd, A., Wu, L., Topp, C., Moran, D., Tolkamp, B., Chadwick, D., 2009 Modelling the effect of climate change on environmental pollution losses from dairy systems in the UK. BC3 Working Paper Series 2009-07. Basque Centre for Climate Change (BC3), Bilbao, Spain.

Del Prado, A., Crosson, P., Olesen, J.E., Rotz, C., 2013. Whole-farm models to quantify greenhouse gas emissions and their potential use for linking climate change mitigation and adaptation in temperate grassland ruminant-based farming systems. Animal 7, 373-385.

Delgado, C.L., 2003. Rising consumption of meat and milk in developing countries has created a new food revolution. J. Nutr. 188, 89075-89105.

Dourmad, J., Ryschawy, J., Trousson, T., Bonneau, M., Gonzàlez, J., Houwers, H., Hviid, M., Zimmer, C., Nguyen, T.L.T., Morgensen, L., 2014. Evaluating environmental impacts of contrasting pig farming systems with life cycle assessment. Animal 8, 2027-2037.

Ellis, J., Bannink, A., France, J., Kebreab, E., Dijkstra, J., 2010. Evaluation of enteric methane prediction equations for dairy cows used in whole farm models. Glob. Chang. Biol. 16, 3246-3256.

FAO, 2013. Mitigation of greenhouse gas emissions in livestock production. Food and Agriculture Association of the United Nations, Rome, Italy.

Generic Algebraic Modeling System Development Corporation, 2012,. Generic Algebraic Modeling System V. 23.8.2. GAMS Development Coporation, Washington, D.C.

Ghebremichael, L.T., Cerosaletti, P.E., Veith, T.L., Rotz, C.A., Hamlett, J.M., Gburek, M.J. 2007. Economic and phosphorus-related effects of precision feeding and forage management at a farm scale. J. Dairy Sci. 90, 3700-3715.

Guerci, M., Knudsen, M.T., Bava, L., Zucali, M., Schönbach, P., Kristensen, T., 2013. Parameters affecting the environmental impact of a range of dairy farming systems in Denmark, Germany and Italy. J. Clean. Prod. 54, 133-141.

Ho, C., Malcolm, B., Doyle, P., 2014. Supplementary feeding options to alleviate the impacts of decreased water availability on dairy-farm economic performance in northern Victoria. Anim. Prod. Sci.

Holter, J., Young, A., 1992. Methane prediction in dry and lactating Holstein cows. J. Dairy Sci. 75, 2165-2175.

Horner, J., Sexten, J., 2014. By-product Feed Price Listing. University of Missouri Extension (URL: http://agebb.missouri.edu/dairy/byprod/bplist.asp, Accessed August 14, 2014)

Hristov, A., Hanigan, M., Cole, A., Todd, R., McAllister, T., Ndegwa, P., Rotz, A., 2011. Review: ammonia emissions from dairy farms and beef feedlots 1. Can. J. Anim. Sci. 91, 1-35.

IPCC, 2006. IPCC Guidelines for National Greenhouse Gas Inventories. Institute for Global Environmental Strategies for the IPCC, Kanagawa, Japan.

IPCC, 2007. Climate Change 2007 - Synthesis Report. Intergovernmnetal Panel on Climate Change, Geneva, Switzerland.

Johnson, K.A., Johnson, D.E., 1995. Methane emissions from cattle. J. Anim. Sci. 73 2483-2492.

Jonker, J., Kohn, R., High, J., 2002. Dairy herd management practices that impact nitrogen utilization efficiency. J. Dairy Sci. 85, 1218-1226.

Kebreab, E., France, J., Beever, D.E., Castillo, A.R., 2001. Nitrogen pollution by dairy cows and its mitigation by dietary manipulation. Nutr. Cycl. Agroecosyst. 60, 275-285.

Lapierre, H., Doepel, L., Pacheco, D., Ouellet, D.R., 2014. Amino acid requirements and post-absorptive metabolism in cattle: Implications for ration formulation, Florida Rumin. Nutr. Symp. 166-178.

Lee, C., Hristov, A., Heyler, K., Cassidy, T., Lapierre, H., Varga, G., Parys, C., 2012. Effects of metabolizable protein supply and amino acid supplementation on nitrogen utilization, milk production, and ammonia emissions from manure in dairy cows. J. Dairy Sci. 95, 5253-5268.

Lovett, D.K., Shalloo, L., Dillon, P., O'Mara, F.P., 2006. A systems approach to quantify greenhouse gas fluxes from pastoral dairy production as affected by management regime. Agric. Syst. 88, 156-179.

Mc Geough, E., Little, S., Janzen, H., McAllister, T., McGinn, S., Beauchemin, K., 2012. Lifecycle assessment of greenhouse gas emissions from dairy production in Eastern Canada: a case study. J. Dairy Sci. 95, 5164-5175.

Mekonnen, M., Hoekstra, A., 2010. The green, blue and grey water footprint of farm animals and animal products.

Meyer, U., Everinghoff, M., Gädeken, D., Flachowsky, G., 2004. Investigations on the water intake of lactating dairy cows. Livestock Prod. Sci. 90, 117-121.

Moe, P., 1981. Energy metabolism of dairy cattle. J. Dairy Sci. 64, 1120-1139. 
Moe, P.W., Tyrrell, H.F., 1979. Methane production in dairy cows. J. Dairy Sci. 62, 1583-1586.

National Research Council, 2001. Nutrient requirements of dairy cattle. seventh ed National Academy Press, Washington, D.C.

Patton, R.A., Hristov, A.N., Lapierre, H., 2014. Protein Feeding and Balancing for Amino Acids in Lactating Dairy Cattle. Veterinary Clinics of North America. Food Anim. Pract.

Pelletier, N., 2008. Environmental performance in the US broiler poultry sector: Life cycle energy use and greenhouse gas, ozone depleting, acidifying and eutrophying emissions. Agric. Syst. 98, 67-73.

Pelletier, N., Ibarburu, M., Xin, H., 2014. Comparison of the environmental footprint of the egg industry in the United States in 1960 and 2010. Poult. Sci. 93, 241-255.

Rius, A., Appuhamy, J., Cyriac, J., Kirovski, D., Becvar, O., Escobar, J., McGilliard, M. Bequette, B., Akers, R., Hanigan, M., 2010a. Regulation of protein synthesis in mammary glands of lactating dairy cows by starch and amino acids. J. Dairy Sci. 93, 3114-3127.

Rius, A., McGilliard, M., Umberger, C., Hanigan, M., 2010b. Interactions of energy and predicted metabolizable protein in determining nitrogen efficiency in the lactating dairy cow. J. Dairy Sci. 93, 2034-2043.

Rotz, C., Montes, F., Chianese, D., 2010. The carbon footprint of dairy production systems through partial life cycle assessment. J. Dairy Sci. 93, 1266-1282.

Sauer, F., Fellner, V., Kinsman, R., Kramer, J., Jackson, H., Lee, A., Chen, S., 1998. Methane output and lactation response in Holstein cattle with monensin or unsaturated fat added to the diet. J. Anim. Sci. 76, 906-914.

Shalloo, L., Dillon, P., Rath, M., Wallace, M., 2004. Description and validation of the Moorepark dairy system model. J. Dairy Sci. 87, 1945-1959.

Spears, R., Young, A., Kohn, R., 2003. Whole-farm phosphorus balance on western dairy farms. J. Dairy Sci. 86, 688-695

Sultana, M.N., Uddin, M.M., Ridoutt, B., Hemme, T., Peters, K., 2015. Benchmarking consumptive water use of bovine milk production systems for 60 geographical regions: An implication for Global Food Security. Glob. Food Sec. 4, 56-68.

Thoma, G., Popp, J., Nutter, D., Shonnard, D., Ulrich, R., Matlock, M., Kim, D.S., Neiderman, Z., Kemper, N., East, C. 2010. Regional analysis of greenhouse gas emissions from milk production practices in the United States. URL: http://www.usdairy.com/ /media/ usd/public/thoma\%20abstract.pdf.pdf (Accessed Jan. 1 2015).
Thoma, G., Popp, J., Nutter, D., Shonnard, D., Ulrich, R., Matlock, M., Kim, D.S., Neiderman, Z., Kemper, N., East, C., 2013a. Greenhouse gas emissions from milk production and consumption in the United States: A cradle-to-grave life cycle assessment circa 2008. Int. Dairy. J. 31, S3-S14.

Thoma, G., Popp, J., Shonnard, D., Nutter, D., Matlock, M., Ulrich, R., Kellogg, W., Kim, D.S. Neiderman, Z., Kemper, N., 2013b. Regional analysis of greenhouse gas emissions from USA dairy farms: A cradle to farm-gate assessment of the American dairy industry circa 2008. Int. Dairy. J. 31, S29-S40.

Thomassen, M., Van Calker, K., Smits, M., Iepema, G., De Boer, I., 2008. Life cycle assessment of conventional and organic milk production in the Netherlands. Agric. Syst. 96, 95-107.

Tozer, P.R., Stokes, J.R., 2001. A multi-objective programming approach to feed ration balancing and nutrient management. Agric. Syst. 67, 201-215.

U.S. Census Bureau, 2013. U.S. Census Bureau International Data Base. U.S. Deparment of Commerce.

USDA/APHIS, 2007. Dairy 2007 Part I: Reference of dairy cattle health and management practices in the United States. USDA/APHIS-VS. Fort Collins, Co.

USDA/ERS, 2012. Data and Statistics. URL: http://quickstats.nass.usda.gov/ (Accessed 15 May 2013).

USDA/NASS, 2007. Census of Agriculture: Farm and Ranch Irrigation Survey. USDA/NASS, Washington, DC.

White, R.R. Brady, M. 2014. Can consumers willingness to pay incentivize adoption of environmental impact reducing technologies in meat animal production? Food Policy 49, 41-49.

White, R.R., Capper, J.L., 2013. An environmental, economic and social assessment of improving cattle finishing weight or average daily gain within U.S. beef production. J. Anim. Sci. 91, 5801-5812.

White, R.R., Brady, M., Capper, J.L., Johnson, K.A., 2014. Optimizing diet and pasture management to improve sustainability of U.S. beef production. Agric. Syst. 130, 1-12.

White, R.R., Brady, M., Capper, J.L., McNamara, J.P., Johnson, K.A., 2015. Cow-calf reproductive, genetic, and nutritional management to improve the sustainability of whole beef production systems. J. Anim. Sci. 93, 3197-3211. 